\title{
Review: UK medicines likely to be affected by the proposed European Medicines Agency's guidelines on phthalates
}

\author{
Lisa Jamieson ${ }^{1}$ and William McCully ${ }^{2^{*}}$
}

\begin{abstract}
Background: Phthalates are excipients in drug formulations. However, concerns have been raised about the effects of particular phthalates on reproduction and development. As a result the EMA has introduced guidelines for permitted daily exposure (PDE) limits for certain phthalates. Therefore, the objective of this study was to identify UK licensed medicines that contain the relevant phthalates and determine if they fall within the recommended PDE.

Methods: The eMC was used to identify which UK licensed medicines contain the phthalates in question. Companies were then contacted for information on the phthalate levels in their products, which was compared with the PDE recommended by the EMA.

Results: The eMC search revealed that 54 medicines contained at least one of the phthalates in question. However, only six medicines, namely Asacol 800 mg MR (Warner Chilcott UK), Epilim 200 Gastro-resistant tablets (Sanofi), Prednisolone $2.5 \mathrm{mg}$ and $5 \mathrm{mg}$ Gastro-resistant tablets (Actavis UK), Vivotif (Crucell Italy S.r.l), and Zentiva $200 \mathrm{mg}$ Gastro-resistant tablets (Winthrop Pharmaceuticals UK), were identified as containing levels that exceeded the recommended PDE.

Conclusions: These findings indicate that very few UK licensed medicines will be affected by the proposed EMA guidelines. For those medicines identified as exceeding recommendations, these findings highlight the need to instigate a risk-benefit review.
\end{abstract}

Keywords: Environmental exposure, Phthalic acids, Dibutyl Phthalate (DBP), Diethyl Phthalate (DEP), Polyvinylacetate Phthalate (PVAP), Excipients, Phthalate

\section{Background}

Phthalates are synthetic chemical esters of phthalic acid, that are broadly divided into low molecular weight (LMW) phthalates, which include the likes of dibutyl phthalate (DBP), diethyl phthalate (DEP) and dimethyl phthalate (DMP); high molecular weight $(\mathrm{HMW})$ phthalates, which encompass butylbenzyl phthalate (BBzP), di-2-ethylhexyl phthalate (DEHP), di-isodecyl phthalate (DiDP), di-isononyl phthalate (DiNP) and di-n-octyl phthalate (DnOP); and phthalate polymers, such as cellulose acetate phthalate (CAP), hydroxypropyl methylcellulose phthalate (HPMCP) and polyvinyl acetate phthalate (PVAP). They confer

\footnotetext{
* Correspondence: wmccully@tillotts.com

${ }^{2}$ Tillotts Pharma UK Ltd., Larbourne Suite, 8 The Stables, Wellingore Hall, Wellingore, Lincoln LN5 OHX, UK

Full list of author information is available at the end of the article
}

numerous properties, including those as a lubricant, a solvent, a softener and a plasticizer, which increases flexibility and durability. Consequently they were once widely found in a variety of consumer products, thus leading to ubiquitous daily exposure [1].

However, concerns have been raised regarding the effects of certain phthalates on reproduction and development. These worries predominantly stem from their endocrinedisrupting properties, and associated anti-androgen implications. They have been well documented pre-clinically, particularly in the rat, where prenatal exposure to particular phthalates has affected male and female offspring, with respect to numerous parameters including anogenital distance (AGD), gender ratio, nipple retention, ear and eye unfolding, vaginal opening and foetal weight and viability [2-4]. In addition, it has been demonstrated that their 
effects are additive when combined with each other, as well as, different classes of anti-androgen chemicals [5]. In fact the endocrine-disrupting effects of phthalates in the rat are so robust that within endocrinology laboratories, phthalates are often used as tools to induce testicular dysgenesis syndrome (TDS). By contrast to the preclinical arena, where there are vast studies evaluating the health implications of phthalates, too many to discuss within the scope of this article, clinical data are few and far between. Those that exist come from human association studies and suggest that prenatal exposure to certain phthalates reduces the AGD amongst male offspring, possibly indicative that it compromises virilisation $[6,7]$. There is also evidence to suggest that prenatal exposure reduces masculine-play behaviour amongst pre-school males [8]. Furthermore, evaluation of phthalate exposure during adulthood demonstrates that it may contribute to both a reduction in the levels of circulating steroid hormones and sperm quality in males, as well as reduced fertility, in both males and females [9-12].

Whilst it is acknowledged that clinical data are limited and, in some cases inconsistent, regulatory bodies affiliated with consumer goods that contain phthalates deemed it necessary to take precautionary measures. Consequently, guidelines have been developed aimed at reducing exposure to certain phthalates in cosmetics [13], childcare articles [14], plastics in contact with food [15] and medical devices [16-18]. Certain medicines represent a source of phthalate exposure, where they exist as excipients, that is, inactive components. Since phthalates are insoluble in acidic environments and soluble in neutral and alkaline conditions, they are commonly used as plasticizing agents in gastroresistant film coatings for tablets, capsules, beads and granules, thus enabling targeted delivery of active ingredient(s) to the more alkaline environment of the intestine. This is likely the reason that drugs for gastrointestinal indications have been identified as particularly high sources of phthalate exposure [19, 20]. Furthermore, animal and human pharmacokinetic studies have shown that LMW phthalates, such as DBP and DEP, have near complete intestinal absorption, with 78-90\% of the administered dose excreted in the urine within 24 h [21-23]. However, for the HMW phthalates CAP, PVAP and HPMCP, there is currently no pharmacokinetic data available.

Accordingly in 2012, the Food and Drug Administration (FDA) also developed guidelines aimed at minimising phthalate exposure in products regulated by the Centre for Drug Evaluation and Research (CDER) [24]. Specifically, the Agency determined that there is evidence that exposure to DBP and DEHP from pharmaceuticals presents a potential risk of developmental and reproductive toxicity. While the Agency recognised that drug products may carry inherent risks, it stated that DBP and DEHP are used as excipients, and safer alternatives are available. Therefore, the Agency recommends that DBP and DEHP be avoided as excipients in CDER-regulated drug and biologic products [24]. In line with the FDA, the EMA's Committee for Medicinal Products for Human Use (CHMP) is currently drafting its own recommendations on the use of phthalates as excipients in human medicinal products [1]. Whilst these guidelines have yet to be finalised, they are expected to propose permitted daily exposures (PDE) of $\leq 0.01,4$ and $2 \mathrm{mg} / \mathrm{kg}$ for DBP, DEP and PVAP, respectively and are predicted to be enforced in 2015. For existing authorised medicinal products, the EMA is proposing to set a time limit of three years (after coming into force of the final guideline) for the implementation of formulation changes and consequential regulatory applications, as necessary. Ahead of their implementation, the authors of this study aimed to identify which United Kingdom (UK)- licensed drugs are likely to be affected by the proposed EMA guidelines, in order to help prepare for potential consequences.

\section{Methods}

The first step in this process was to identify which UK licensed medicines contain at least one of the three precautionary phthalates, DBP, DEP and PVAP, named in the draft EMA guidelines. The electronic Medicines Compendium (eMC) [25] was deemed an effective way to find these medicines, as it contains up to date information about most medicines licensed in the UK and is checked and approved by either the Medicines and Healthcare products Regulatory Agency (MHRA) or the EMA. The eMC was utilised via the algorithm depicted in Fig. 1.

The eMC provided the medical information email address associated with each medicine found to contain the precautionary phthalates. The next stage was to contact the companies affiliated with each of the medicines identified as containing the precautionary phthalates. In many cases, a single medical information address was affiliated with numerous products, thus it was only necessary to issue emails to 28 different medical information companies, requesting information about the maximum daily exposure of the relevant phthalate(s) in their product(s). Twenty-seven companies were contacted using the medical information email address provided by the eMC and one was contacted by an online enquiry form. The companies were made aware of the proposed EMA guidelines and their phthalate containing product(s) was identified together with a request for information on the maximum daily exposure of the affiliated phthalate(s).

\section{Results}

The eMC search to identify UK medicines containing at least one of the three precautionary phthalates, DBP, DEP and PVAP, named in the draft EMA guidelines, produced 50 hits (information correct as of $9^{\text {th }}$ June 2014), one of which was deemed a false positive because the drug was 


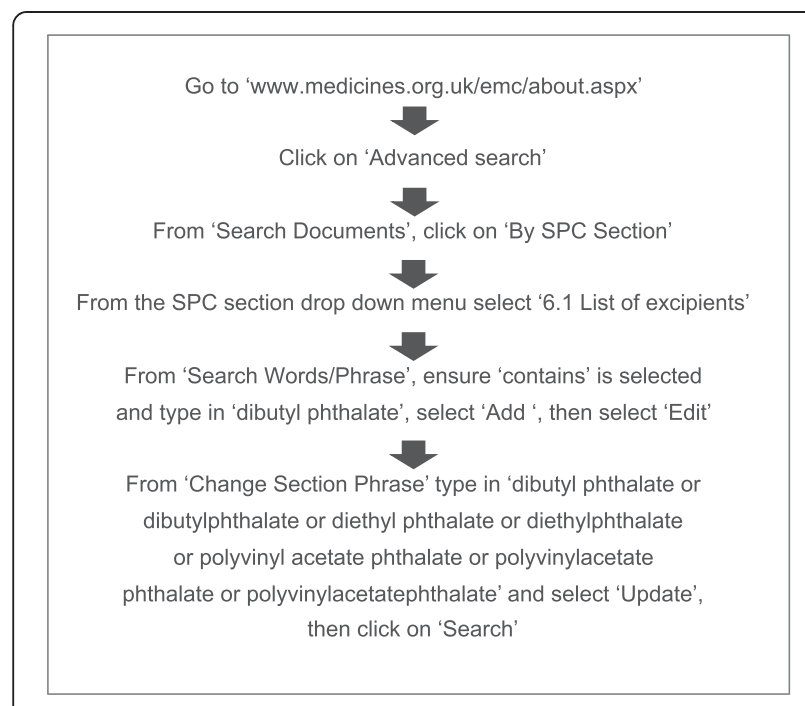

Fig. 1 Algorithm for using the eMC to identify which UK licensed medicines contain at least one of the three precautionary phthalates, DBP, DEP and PVAP, named in the draft EMA guidelines on the use of phthalates as excipients in human medicinal products

listed as discontinued (Maxolon SR $15 \mathrm{mg}$ Capsules). The remaining 49 hits, consisted of 54 branded medicines, five of which contained DBP alone, 17 contained DEP alone, 27 contained PVAP alone, four contained DEP in combination with PVAP and one contained DBP in combination with DEP (Table 1). It should be noted that this list will only contain those drugs registered on the eMC.

Whilst some companies provided maximum daily exposure as requested, thus enabling direct comparison with those set out in the draft guidelines, others did not specify exposure levels but instead commented on how exposure compared with the guidelines. In some instances, companies stipulated the amount of phthalate present in a single unit of the medicine, thus requiring the authors to calculate the maximum daily exposure based on maximum indicated dose as per the 'summary of product characteristics' (SPC). There were five cases where companies stated that they were unable to quantify (UTQ) exposure and for 11 products, companies refused to declare (RTD). Remaining companies provided no response (NR) at all which amounted to 12 products. Responses are summarised in Table 1, however, we were unable to include the phthalate content for 23 products because either the licence holder refused to declare or provided no response.

The proposed permitted daily exposures (PDE) in the EMA guidance equates to $<0.7 \mathrm{mg}$ for DBP, $280 \mathrm{mg}$ for DEP and $140 \mathrm{mg}$ for PVAP, for an individual with $70 \mathrm{~kg}$ body weight.

\section{Phthalate in tablet/capsule logo ink}

For some preparations, the phthalate was contained in the tablet/capsule logo ink on the surface of the dosage formulation. In all of these preparations, the phthalate was PVAP. For those companies who responded, the level of PVAP in the ink in each preparation was below proposed EMA PDE in all products. In some cases, the manufacturer declared that the phthalate content was so low per dosage form that it was negligible or too low to measure accurately.

\section{Phthalate in tablet/capsule/liquid formulation}

Where the phthalate was contained as an excipient within the dosage form, the level of phthalate varied considerably. The EMA proposes that the presence in medicinal products of DBP, DEP or PVAP at levels giving rise to daily exposures above the PDEs may be accepted as exceptions, on a case-by-case basis taking into consideration the intended patient population, the disease seriousness and the presence (or not) of alternative treatment options. Furthermore, the EMA also proposes that in severe or terminal disease conditions, the strict application of the PDE may not be considered necessary for DBP, DEP or PVAP-containing medicinal products, where the risk of reproductive and developmental toxicity is outweighed by the benefits of treatment for patients.

Consequently, the drugs were assessed in terms of whether or not they are used acutely or chronically. Where a drug may be used in either an acute or a chronic condition, it was categorised as "chronic", due to the possibility that the drug may be prescribed on a long-term basis. Drugs were also categorised according to whether or not they are licensed for use in pregnancy. The SPC for some drugs advises caution in pregnancy or the drug may be used where the benefit outweighs the risk. For both of these categories, drugs were described as "benefit > risk" (Table 1).

Where the licence holder supplied information regarding DBP content, the level was above the proposed EMA PDE of $0.7 \mathrm{mg}$ for $70 \mathrm{~kg}$ body weight in Asacol $800 \mathrm{mg}$ MR (Warner Chilcott UK Ltd) and Vivotif (Crucell Italy S.r.l), the levels being $48 \mathrm{mg}$ and $8 \mathrm{mg}$, respectively, at the maximum daily dose.

For DEP, the proposed EMA PDE is $280 \mathrm{mg}$ per $70 \mathrm{~kg}$ body weight. Where the licence holder supplied information, this level was not exceeded at maximum daily dose in the DEP-containing products.

The proposed EMA PDE for PVAP is $140 \mathrm{mg}$ per $70 \mathrm{~kg}$ body weight. There were two PVAP-containing products where the level exceeded this. These were Prednisolone $2.5 \mathrm{mg}$ Gastro-resistant Tablets and Prednisolone $5 \mathrm{mg}$ Gastro-resistant Tablets (Actavis UK Ltd), where the levels at the maximum licensed daily dose were 288 and $144 \mathrm{mg}$, respectively.

Four preparations contained a combination of DEP and PVAP. Of these, Epilim 200 Gastro-resistant Tablets 
Table 1 UK licensed medicines that contain DBP, DEP and/or PVAP and respective maximum daily exposures relative to proposed EMA guidelines

\begin{tabular}{|c|c|c|c|c|c|c|c|}
\hline Trade Name (generic name) & License holder & Phthalate & $\begin{array}{l}\text { Phthalate content }(\mathrm{mg}) \\
\text { per tablet/capsule }\end{array}$ & $\begin{array}{l}\text { Maximum licensed daily } \\
\text { dose of drug }\end{array}$ & $\begin{array}{l}\text { Phthalate }(\mathrm{mg}) \text { at } \\
\text { maximum daily dose }\end{array}$ & $\begin{array}{l}\text { Chronic/ } \\
\text { Acute }\end{array}$ & $\begin{array}{l}\text { Use in } \\
\text { pregnancy }\end{array}$ \\
\hline \multicolumn{8}{|l|}{ Phthalate in tablet/capsule/liquid formulation } \\
\hline Asacol 800 mg MR Tablets (mesalazine) & Warner Chilcott UK Ltd & DBP & $8.00^{c}$ & $4.8 \mathrm{mg}$ & 48.00 & Chronic & Benefit>Risk \\
\hline Coracten XL 30 mg (Nifedipine) & UCB Pharma Ltd & DBP & 0.14 & $90 \mathrm{mg}$ & 0.42 & Chronic & No \\
\hline Coracten XL 60 mg (Nifedipine) & UCB Pharma Ltd & DBP & 0.28 & $90 \mathrm{mg}$ & 0.28 & Chronic & No \\
\hline Occlusal (Salicylic acid) & Alliance Pharmaceuticals & DBP & N/A & RTD & RTD & Acute & Benefit>Risk \\
\hline $\begin{array}{l}\text { Timodine Cream (Nystatin, Dimeticone, } \\
\text { Hydrocortisone \& Benzalkonium Chloride) }\end{array}$ & Alliance Pharmaceuticals & DBP & N/A & RTD & RTD & Acute & No \\
\hline Vivotif (Salmonella enterica serovar Typhi) & Crucell Italy S.r.l & $\begin{array}{l}\text { DBP / } \\
\text { DEP }\end{array}$ & $8.00 / 8.00$ & 1 tablet & $8.00 / 8.00$ & Acute & Benefit>Risk \\
\hline $\begin{array}{l}\text { Kenzem } 120 \text { mg SR Capsules (Diltiazem } \\
\text { hydrochloride) }\end{array}$ & Kent Pharmaceuticals & DEP & $N R$ & $480 \mathrm{mg}$ & NR & Chronic & No \\
\hline $\begin{array}{l}\text { Kenzem } 90 \text { mg SR Capsules (Diltiazem } \\
\text { hydrochloride) }\end{array}$ & Kent Pharmaceuticals & DEP & NR & $480 \mathrm{mg}$ & NR & Chronic & No \\
\hline $\begin{array}{l}\text { Kenzem } 60 \text { mg SR Capsules (Diltiazem } \\
\text { hydrochloride) }\end{array}$ & Kent Pharmaceuticals & DEP & NR & $480 \mathrm{mg}$ & NR & Chronic & No \\
\hline $\begin{array}{l}\text { Omeprazole } 40 \text { mg Gastro-resistant Capsules, Hard } \\
\text { (Omeprazole) }\end{array}$ & Accord Healthcare Ltd & DEP & 0.15 & $120 \mathrm{mg}$ & 0.45 & Chronic $^{d}$ & Yes \\
\hline $\begin{array}{l}\text { Omeprazole } 20 \text { mg Gastro-resistant Capsules, Hard } \\
\text { (Omeprazole) }\end{array}$ & Accord Healthcare Ltd & DEP & 0.15 & $120 \mathrm{mg}$ & 0.90 & Chronic $^{d}$ & Yes \\
\hline $\begin{array}{l}\text { Reminyl XL } 24 \text { mg Prolonged Release Capsules } \\
\text { (Galantamine) }\end{array}$ & Shire Pharmaceuticals Ltd & DEP & NR & $24 \mathrm{mg}$ & NR & Chronic & Benefit>Risk \\
\hline $\begin{array}{l}\text { Reminyl XL } 16 \text { mg Prolonged Release Capsules } \\
\text { (Galantamine) }\end{array}$ & Shire Pharmaceuticals Ltd & DEP & NR & $24 \mathrm{mg}$ & NR & Chronic & Benefit>Risk \\
\hline $\begin{array}{l}\text { Reminyl XL } 8 \text { mg Prolonged Release Capsules } \\
\text { (Galantamine) }\end{array}$ & Shire Pharmaceuticals Ltd & DEP & $N R$ & $24 \mathrm{mg}$ & NR & Chronic & Benefit $>$ Risk \\
\hline $\begin{array}{l}\text { Rheumatac Retard } 75 \text { mg Tablets (Diclofenac } \\
\text { sodium) }\end{array}$ & $\begin{array}{l}\text { Adipharm Mercury } \\
\text { Company Ltd }\end{array}$ & DEP & 0.95 & $150 \mathrm{mg}$ & 1.90 & Acute & No \\
\hline Surgical Spirit BP (Virgin castor oil \& Methyl salicylate & Thornton \& Ross Ltd & DEP & N/A & N/A & UTQ & Acute & Benefit>Risk \\
\hline $\begin{array}{l}\text { Videx EC } 400 \text { mg Gastro-resistant Capsules } \\
\text { (Didanosine) }\end{array}$ & $\begin{array}{l}\text { Bristol-Myers Squibb } \\
\text { Pharmaceuticals Ltd }\end{array}$ & DEP & RTD & $400 \mathrm{mg}$ & RTD & Chronic & Benefit>Risk \\
\hline $\begin{array}{l}\text { Videx EC } 250 \text { mg Gastro-resistant Capsules } \\
\text { (Didanosine) }\end{array}$ & $\begin{array}{l}\text { Bristol-Myers Squibb } \\
\text { Pharmaceuticals Ltd }\end{array}$ & DEP & RTD & $400 \mathrm{mg}$ & RTD & Chronic & Benefit>Risk \\
\hline $\begin{array}{l}\text { Videx EC } 200 \text { mg Gastro-resistant Capsules } \\
\text { (Didanosine) }\end{array}$ & $\begin{array}{l}\text { Bristol-Myers Squibb } \\
\text { Pharmaceuticals Ltd }\end{array}$ & DEP & RTD & $400 \mathrm{mg}$ & RTD & Chronic & Benefit>Risk \\
\hline $\begin{array}{l}\text { Videx EC } 125 \text { mg Gastro-resistant Capsules } \\
\text { (Didanosine) }\end{array}$ & $\begin{array}{l}\text { Bristol-Myers Squibb } \\
\text { Pharmaceuticals Ltd }\end{array}$ & DEP & RTD & $400 \mathrm{mg}$ & RTD & Chronic & Benefit>Risk \\
\hline Volsaid Retard 100 mg Tablets (Diclofenac Sodium) & Chiesi Ltd & DEP & 1.27 & $100 \mathrm{mg}$ & 1.27 & Acute & No \\
\hline
\end{tabular}


Table 1 UK licensed medicines that contain DBP, DEP and/or PVAP and respective maximum daily exposures relative to proposed EMA guidelines (Continued)

\begin{tabular}{|c|c|c|c|c|c|c|c|}
\hline Volsaid Retard 75 mg Tablets (Diclofenac Sodium) & Chiesi Ltd & DEP & 0.95 & $150 \mathrm{mg}$ & 1.90 & Acute & No \\
\hline Boots Constipation Relief Tablets 40s (Bisacodyl) & $\begin{array}{l}\text { Dr. Reddy's Laboratories } \\
\text { (UK) Ltd }\end{array}$ & DEP & NR & 2 tablets & NR & Acute & No \\
\hline $\begin{array}{l}\text { Epilim } 500 \text { Gastro-resistant Tablets (Sodium } \\
\text { valproate) }\end{array}$ & Sanofi & $\begin{array}{l}\text { DEP / } \\
\text { PVAP }\end{array}$ & $2.31 / 23.31$ & $2500 \mathrm{mg}$ & $11.55 / 116.55$ & Chronic & No \\
\hline $\begin{array}{l}\text { Epilim } 200 \text { Gastro-resistant Tablets (Sodium } \\
\text { valproate) }\end{array}$ & Sanofi & $\begin{array}{l}\text { DEP / } \\
\text { PVAP }\end{array}$ & $1.23 / 12.43$ & $2500 \mathrm{mg}$ & $14.76 / 149.16$ & Chronic & No \\
\hline $\begin{array}{l}\text { Zentiva } 500 \text { mg Gastro-resistant Tablets (Sodium } \\
\text { valproate) }\end{array}$ & $\begin{array}{l}\text { Winthrop Pharmaceuticals } \\
\text { UK Ltd }\end{array}$ & $\begin{array}{l}\text { DEP / } \\
\text { PVAP }\end{array}$ & $2.31 / 23.31$ & 2500 mg & $11.55 / 116.55$ & Chronic & No \\
\hline $\begin{array}{l}\text { Zentiva } 200 \text { mg Gastro-resistant Tablets (Sodium } \\
\text { valproate) }\end{array}$ & $\begin{array}{l}\text { Winthrop Pharmaceuticals } \\
\text { UK Ltd }\end{array}$ & $\begin{array}{l}\text { DEP / } \\
\text { PVAP }\end{array}$ & $1.23 / 12.43$ & $2500 \mathrm{mg}$ & $14.76 / 149.16$ & Chronic & No \\
\hline $\begin{array}{l}\text { Boots Alternatives Laxative Tablets (Senna, Aloin, } \\
\text { Cascara bark extract) }\end{array}$ & $\begin{array}{l}\text { G.R. Lane Health Products } \\
\text { Ltd }\end{array}$ & PVAP & 2.10 & 2 tablets & 4.20 & Acute & No \\
\hline $\begin{array}{l}\text { Boots Period Pain Relief } 250 \text { mg Gastro-resistant Tab- } \\
\text { lets (Naproxen) }\end{array}$ & Teva UK Ltd & PVAP & NR & $500 \mathrm{mg}$ & NR & Acute & No \\
\hline $\begin{array}{l}\text { Deltacortril } 2.5 \mathrm{mg} \text { Gastro-resistant Tablets } \\
\text { (Prednisolone) }\end{array}$ & Alliance Pharmaceuticals & PVAP & RTD & $60 \mathrm{mg}$ & RTD & Chronic $^{d}$ & Benefit>Risk \\
\hline $\begin{array}{l}\text { Deltacortril } 5 \mathrm{mg} \text { Gastro-resistant Tablets } \\
\text { (Prednisolone) }\end{array}$ & Alliance Pharmaceuticals & PVAP & RTD & $60 \mathrm{mg}$ & RTD & Chronic $^{d}$ & Benefit>Risk \\
\hline Disipal 50 mg Tablets (Orphenadrine hydrochloride) & Astellas Pharma Ltd & PVAP & 17.30 & $400 \mathrm{mg}$ & 138.40 & Chronic & Benefit>Risk \\
\hline $\begin{array}{l}\text { Feminax Ultra } 250 \text { mg Gastro-resistant Tablets } \\
\text { (Naproxen) }\end{array}$ & Teva UK Ltd & PVAP & NR & $750 \mathrm{mg}$ & NR & Acute & No \\
\hline $\begin{array}{l}\text { Ferrous Gluconate } 300 \text { mg Tablets (Ferrous } \\
\text { gluconate) }\end{array}$ & Kent Pharmaceuticals & PVAP & NR & $1800 \mathrm{mg}$ & NR & Chronic $^{d}$ & Yes \\
\hline Nardil 15 mg Tablets (Phenelzine) & $\begin{array}{l}\text { Archimedes Pharma UK } \\
\text { Ltd }\end{array}$ & PVAP & 1.42 & $90 \mathrm{mg}$ & 8.52 & Chronic & No \\
\hline $\begin{array}{l}\text { Prednisolone } 5 \text { mg Gastro-resistant Tablets } \\
\text { (Prednisolone) }\end{array}$ & Actavis UK Ltd & PVAP & 12.00 & $60 \mathrm{mg}$ & 144.00 & Chronic $^{d}$ & Benefit>Risk \\
\hline $\begin{array}{l}\text { Prednisolone } 2.5 \mathrm{mg} \text { Gastro-resistant Tablets } \\
\text { (Prednisolone) }\end{array}$ & Actavis UK Ltd & PVAP & 12.00 & $60 \mathrm{mg}$ & 288.00 & Chronic $^{d}$ & Benefit>Risk \\
\hline Pancrex Granules (Pancreatin) & $\begin{array}{l}\text { Essential Pharmaceuticals } \\
\text { Ltd }\end{array}$ & PVAP & RTD & variable $^{a}$ & RTD & Chronic & Benefit>Risk \\
\hline Pancrex V Tablets (Pancreatin) & $\begin{array}{l}\text { Essential Pharmaceuticals } \\
\text { Ltd }\end{array}$ & PVAP & RTD & variable $^{a}$ & RTD & Chronic & Benefit>Risk \\
\hline Pancrex V Forte Tablets (Pancreatin) & $\begin{array}{l}\text { Essential Pharmaceuticals } \\
\text { Ltd }\end{array}$ & PVAP & RTD & variable $^{a}$ & RTD & Chronic & Benefit>Risk \\
\hline \multicolumn{8}{|l|}{ Phthalate in tablet/capsule logo ink } \\
\hline Aloxi 500 нg Soft Capsules (Palonosetron) & Sinclair IS Pharma & PVAP & UTQ & $500 \mu \mathrm{g}$ & UTQ & Acute & No \\
\hline Amitiza 24 ug Soft Capsules (Lubiprostone) & Sucampo Pharma Europe & PVAP & 0.21 & $48 \mu \mathrm{g}$ & 0.42 & Acute & No \\
\hline
\end{tabular}


Table 1 UK licensed medicines that contain DBP, DEP and/or PVAP and respective maximum daily exposures relative to proposed EMA guidelines (Continued)

\begin{tabular}{|c|c|c|c|c|c|c|c|}
\hline $\begin{array}{l}\text { Anadin Ultra Double Strength/LiquiFast } 400 \text { mg } \\
\text { Capsules (Aspirin) }\end{array}$ & $\begin{array}{l}\text { Pfizer Consumer } \\
\text { Healthcare }\end{array}$ & PVAP & $<0.01$ & $1200 \mathrm{mg}$ & 0.03 & Acute & No \\
\hline Anadin Ultra/LiquiFast 200 mg Capsules (Aspirin) & $\begin{array}{l}\text { Pfizer Consumer } \\
\text { Healthcare }\end{array}$ & PVAP & $<0.01$ & $1200 \mathrm{mg}$ & 0.05 & Acute & No \\
\hline Aptivus 250 mg soft Capsules (Tipranavir) & Boehringer Ingelheim Ltd & PVAP & UTQ & 1000 mg & UTQ & Chronic & Benefit>Risk \\
\hline $\begin{array}{l}\text { Benadryl Allergy Liquid Release } 10 \text { mg Capsules } \\
\text { (Certirizine dihydrochloride) }\end{array}$ & McNeil Products Ltd & PVAP & 1.00 & $10 \mathrm{mg}$ & 1 & Chronic $^{d}$ & Benefit>Risk \\
\hline Nurofen Express 200 mg Liquid Capsules (Ibuprofen) & $\begin{array}{l}\text { Reckitt Benckiser } \\
\text { Healthcare (UK) Ltd }\end{array}$ & PVAP & NR & $1200 \mathrm{mg}$ & NR & Acute & No \\
\hline Nurofen Express 400 mg Liquid Capsules (Ibuprofen) & $\begin{array}{l}\text { Reckitt Benckiser } \\
\text { Healthcare (UK) Ltd }\end{array}$ & PVAP & NR & $1200 \mathrm{mg}$ & NR & Acute & No \\
\hline Targretin 75 mg Capsules (Bexarotene) & Eisai Ltd & PVAP & UTQ & 21 capsules $^{b}$ & UTQ & Acute & No \\
\hline Xtandi 40 mg Soft Capsules (Enzalutamide) & Astellas Pharma Ltd & PVAP & UTQ & $160 \mathrm{mg}$ & UTQ & Acute & No \\
\hline Zemplar Soft Capsules 2 g (Paricalcitol) & AbbVie Ltd & PVAP & 0.86 & $32 \mu g$ & 13.76 & Chronic & Benefit>Risk \\
\hline Zemplar Soft Capsules 1 g (Paricalcitol) & AbbVie Ltd & PVAP & 0.86 & $32 \mu \mathrm{g}$ & 27.52 & Chronic & Benefit>Risk \\
\hline
\end{tabular}

AbbVie Ltd

PVAP $\quad 0.86$

$32 \mu \mathrm{g}$

due to their dose increment, (i.e. sodium valproate $200 \mathrm{mg}$ - max dose $2500 \mathrm{mg}$ ), the maximum achievable dose within the product license was used

UTQ denotes unable to quantify, RTD denotes licence holder refused to declare, NR denotes no response

b Based on a dose of $650 \mathrm{mg} / \mathrm{m}^{2} /$ day for a person with a body surface area of $2.38-2.62 \mathrm{~m}^{2}$

${ }^{\mathrm{C}}$ Information in the public domain [26, 27], license holder refused to confirm

${ }^{\mathrm{d}}$ These medications are also used in acute settings 
(Sanofi) and Zentiva $200 \mathrm{mg}$ Gastro-resistant Tablets (Winthrop Pharmaceuticals UK Limited) contained a level of PVAP that was above the EMA PDE. The PVAP level was $149.16 \mathrm{mg}$ in both sodium valproate $200 \mathrm{mg}$ formulations.

\section{Discussion}

\section{Summary}

The aim of this study was to identify which UK licensed medicines are likely to be affected by proposed EMA guidelines on the use of phthalates as excipients in human medicinal products. Although we attempted to identify as many phthalate-containing preparations as possible by reviewing SPCs, this list cannot be considered exhaustive. For 23 products, the licence holder refused to declare the phthalate content or gave no response. At face value, it appeared that many medicines would be impacted by the recommendations as 54 medicines were identified as containing the precautionary phthalates DBP, DEP and PVAP, named in the guidelines. However, for those medicines where companies responded, once maximum daily phthalate exposures were established, only six branded medicines, namely Asacol 800 mg MR (Warner Chilcott UK Ltd), Epilim 200 Gastro-resistant Tablets (Sanofi), Prednisolone 2.5 and $5 \mathrm{mg}$ Gastro-resistant Tablets (Actavis UK Ltd), Vivotif (Crucell Italy S.r.l), and Zentiva $200 \mathrm{mg}$ Gastro-resistant Tablets (Winthrop Pharmaceuticals UK Limited), were identified as exceeding the EMA's proposed recommendations. Thus, this study will help to appease those concerned about the implications of enforcement of these guidelines.

\section{Strengths and limitations}

To the authors' knowledge, this study has provided the first review of the presence of phthalates in UK licenced medications. Furthermore, it has identified, where possible, which phthalate-containing medications will be affected by EMA guidance once it comes into practice. By virtue of the limited information in the public domain and the proprietary nature of drug formulations, information on the concentration of phthalates was limited to only $57 \%$ of the drugs identified. This highlights the potential difficulty in clinical practice when undertaking a risk/benefit approach in the preceding 3 years before the enforcement of this guidance. In addition, not all SPC's are available on the $\mathrm{eMC}$, further hindering the ability of making an informed decision in certain patient populations.

\section{Conclusion}

For those medicines identified as exceeding the EMA's recommendations, this study has highlighted the need to instigate a risk-benefit review, particularly in patients of childbearing age and/or with chronic conditions. To facilitate this process, the EMA, suggests taking into account factors such as the presence of non-phthalate containing alternatives, the intended patient population and the severity of the disease being treated.

\section{Abbreviations}

AGD: Anogenital distance; BBzP: Butylbenzyl phthalate; CAP: Cellulose acetate phthalate; CDER: Centre for Drug Evaluation and Research; DBP: Dibutyl phthalate; DEHP: Di-2-ethylhexyl phthalate; DEP: Diethyl phthalate; DiDP: Di-isodecyl phthalate; DMP: Dimethyl phthalate; DnOP: Di-n-octyl phthalate; EMA: European Medicines Agency; eMC: Electronic medicines compendium; FDA: Food and Drug Administration; HMW: High molecular weight; HPMCP: Hydroxypropyl methylcellulose phthalate; LMW: Low molecular weight; MHRA: Medicines and Healthcare products Regulatory Agency; NR: No response; PDE: Permitted daily exposure; PVAP: Polyvinylacetate phthalate; RTD: Refused to declare; SPC: Summary of product characteristics; TDS: Testicular dysgenesis syndrome; UTQ: Unable to quantify.

\section{Competing Interests}

Lisa Jamieson has served as a consultant for Tillotts Pharma UK Ltd and has received research funding from Tillotts Pharma UK Ltd.

William McCully is an employee of Tillotts Pharma UK Ltd.

\section{Authors' contributions}

$\downarrow J$ carried out the research of this study and assisted in the production of the manuscript. WM conceived of the study, participated in its research and assisted in the production of the manuscript. All authors read and approved the final manuscript.

\section{Funding}

The study was funded by Tillotts Pharma UK Ltd.

\section{Author details}

${ }^{1}$ Enucleo Limited, Farnham, Surrey, UK. ${ }^{2}$ Tillotts Pharma UK Ltd., Larbourne Suite, 8 The Stables, Wellingore Hall, Wellingore, Lincoln LN5 OHX, UK.

Received: 3 December 2014 Accepted: 26 May 2015

Published online: 13 June 2015

\section{References}

1. European Medicines Agency. Guideline on the use of phthalates as excipients in human medicinal products: EMA/CHMP/SWP/362974/2012. http:// www.ema.europa.eu/docs/en_GB/document_library/Scientific_guideline/ 2013/05/WC500143140.pdf. Accessed 10 July 2014.

2. Lee KY, Shibutani M, Takagi H, Kato N, Takigami S, Uneyama C, et al. Diverse developmental toxicity of di-n-butyl phthalate in both sexes of rat offspring after maternal exposure during the period from late gestation through lactation. Toxicology. 2004;203:221-38.

3. Fujii S, Yabe K, Furukawa M, Hirata M, Kiguchi M, Ikka T. A two-generation reproductive toxicity study of diethyl phthalate (DEP) in rats. J Toxicol Sci. 2005;30:97-116.

4. Schoneker DR, DeMerlis CC, Borzelleca JF. Evaluation of the toxicity of polyvinylacetate phthalate in experimental animals. Food Chem Toxicol. 2003;41:405-13.

5. Rider CV, Furr J, Wilson VS. A mixture of seven antiandrogens induces reproductive malformations in rats. Int J Androl. 2008;31:249-62.

6. Swan SH, Main KM, Liu F, Stewart SL, Kruse RL, Calafat AM, et al. Decrease in anogenital distance among male infants with prenatal phthalate exposure. Environ Health Perspect. 2005;113:1056-61.

7. Suzuki Y, Yoshinaga J, Mizumoto Y, Serizawa S, Shiraishi H. Foetal exposure to phthalate esters and anogenital distance in male newborns. Int J Androl. 2012;35:236-44.

8. Swan SH, Liu F, Hines M, Kruse RL, Wang C, Redmon JB, et al. Prenatal phthalate exposure and reduced masculine play in boys. Int J Androl. 2010;33:259-69.

9. Meeker JD, Calafat AM, Hauser R. Urinary metabolites of di(2-ethylhexyl) phthalate are associated with decreased steroid hormone levels in adult men. J Androl. 2009;30:287-97.

10. Pan G, Hanaoka T, Yoshimura M, Zhang S, Wang P, Tsukino H, et al. Decreased serum free testosterone in workers exposed to high levels of di-n-butyl 
phthalate (DBP) and di-2-ethylhexyl phthalate (DEHP): a cross-sectional study in China. Environ Health Perspect.

2006;114:1643-8.

11. Hauser R, Meeker JD, Duty S, Silva MJ, Calafat AM. Altered semen quality in relation to urinary concentrations of phthalate monoester and oxidative metabolites. Epidemiology. 2006;17:682-91.

12. Tranfo G, Caporossi L, Paci E, Aragone C, Romazi D, De Carolis C, et al. Urinary phthalate monoesters concentration in couples with infertility problems. Toxicol Lett. 2012;213:15-20.

13. Council of the European Union. Council Directive 76/768/EEC of 27 July 1976 on the approximation of the laws of the Member States relating to cosmetic products. OJ L. 1976;262:169-200.

14. Council of the European Union. Directive 2005/84/EC of the European parliament and of the council of 14 December 2005 amending for the $22^{\text {nd }}$ time Council Directive 76/769/EEC on the approximation of the laws, regulations and administrative provisions of the Member States relating to restrictions on the marketing and use of certain dangerous substances and preparations (phthalates in toys and childcare articles). OJ L. 2005;344:40-3.

15. Council of the European Union. Commission directive 2007/19/EC of 30 March 2007 amending directive 2002/72/EC relating to plastic materials and articles intended to come into contact with food and Council Directive 85/ 572/EEC laying down the list of simulants to be used for testing migration of constituents of plastic materials and articles intended to come into contact with foodstuffs. OJ L. 2007:91:17-36.

16. Council of the European Union. Directive 2007/47/EC of the European parliament and of the council of 5 September 2007 amending Council Directive 90/385/EEC on the approximation of the laws of the Member States relating to active implantable medical devices, Council Directive 93/42/EEC concerning medical devices and Directive 98/8/EC concerning the placing of biocidal products on the market. OJ L. 2007;247:21-55.

17. Huang PC, Kuo PL, Chou YY, Lin SJ, Lee CC. Association between prenatal exposure to phthalates and the health of newborns. Environ Int. 2009:35:14-20

18. Jönsson BA, Richthoff J, Rylander L, Giwercman A, Hagmar L. Urinary phthalate metabolites and biomarkers of reproductive function in young men. Epidemiology. 2005;16:487-93.

19. Hernández-Díaz S, Su YC, Mitchell AA, Kelley KE, Calafat AM, Hauser R. Medications as a potential source of exposure to phthalates among women of childbearing age. Reprod Toxicol. 2013;37:1-5.

20. Hauser R, Duty S, Godfrey-Bailey L, Calafat AM. Medications as a source of human exposure to phthalates. Environ Health Perspect. 2004;112:751-3.

21. Api AM. Toxicological profile of diethyl phthalate: a vehicle for fragrance and cosmetic ingredients. Food Chem Toxicol. 2001;39(2):97-108.

22. Koch HM, Christensen KL, Harth V, Lorber M, Brüning T. Di-n-butyl phthalate (DnBP) and diisobutyl phthalate (DiBP) metabolism in a human volunteer after single oral doses. Arch Toxicol. 2012;86(12):1829-39.

23. Seckin E, Fromme H, Völkel W. Determination of total and free mono-n-butyl phthalate in human urine samples after medication of a di-n-butyl phthalate containing capsule. Toxicol Lett. 2009;188(1):33-7.

24. U.S Department of Health and Human Services Food and Drug Administration Center for Drug Evaluation and Research (CDER). Guidance for Industry Limiting the Use of Certain Phthalates as Excipients in CDER-Regulated Products. http:// www.fda.gov/Drugs/GuidanceComplianceRegulatoryInformation/Guidances/ ucm330792.htm. Accessed 10 July 2014

25. Electronic medicines compendium (eMC). www.medicines.org.uk/emc. Accessed 10 July 2014

26. Warner Chilcott. Asacol HD highlights of prescribing information. http:// pi.actavis.com/data_stream.asp?product_group $=1875 \& \mathrm{p}=$ pi\&language $=\mathrm{E}$ Accessed 10 July 2014

27. U.S Food and Drug Administration. Asacol (mesalamine) delayed release tablets. http://www.fda.gov/Safety/MedWatch/Safetylnformation/ ucm215476.htm. Accessed 10 July 2014

\section{Submit your next manuscript to BioMed Central and take full advantage of:}

- Convenient online submission

- Thorough peer review

- No space constraints or color figure charges

- Immediate publication on acceptance

- Inclusion in PubMed, CAS, Scopus and Google Scholar

- Research which is freely available for redistribution 